\title{
Explaining foreign direct investment in Central and Eastern Europe: an extended gravity approach
}

Citation for published version (APA):

Bos, J. W. B., \& van de Laar, M. M. (2004). Explaining foreign direct investment in Central and Eastern Europe: an extended gravity approach. METEOR, Maastricht University School of Business and Economics. METEOR Research Memorandum No. 031 https://doi.org/10.26481/umamet.2004031

Document status and date:

Published: 01/01/2004

DOI:

10.26481/umamet.2004031

Document Version:

Publisher's PDF, also known as Version of record

\section{Please check the document version of this publication:}

- A submitted manuscript is the version of the article upon submission and before peer-review. There can be important differences between the submitted version and the official published version of record. People interested in the research are advised to contact the author for the final version of the publication, or visit the DOI to the publisher's website.

- The final author version and the galley proof are versions of the publication after peer review.

- The final published version features the final layout of the paper including the volume, issue and page numbers.

Link to publication

\footnotetext{
General rights rights.

- You may freely distribute the URL identifying the publication in the public portal. please follow below link for the End User Agreement:

www.umlib.nl/taverne-license

Take down policy

If you believe that this document breaches copyright please contact us at:

repository@maastrichtuniversity.nl

providing details and we will investigate your claim.
}

Copyright and moral rights for the publications made accessible in the public portal are retained by the authors and/or other copyright owners and it is a condition of accessing publications that users recognise and abide by the legal requirements associated with these

- Users may download and print one copy of any publication from the public portal for the purpose of private study or research.

- You may not further distribute the material or use it for any profit-making activity or commercial gain

If the publication is distributed under the terms of Article $25 \mathrm{fa}$ of the Dutch Copyright Act, indicated by the "Taverne" license above, 


\title{
Explaining Foreign Direct Investment in Central and Eastern Europe: an Extended Gravity Approach
}

\author{
J.W.B. Bos ${ }^{\mathrm{a}, 1}$, M. van de Laar ${ }^{\mathrm{b}, 1}$ \\ aj.bos@econ.uu.nl, Utrecht School of Economics, Utrecht University, Vredenburg \\ 138, 3511 BG, Utrecht, the Netherlands \\ bm.vandelaar@algec.unimaas.nl,Economics Department, Faculty of Economics \\ and Business Administration, Maastricht University, P.O. Box 616, 6200 MD \\ Maastricht, the Netherlands
}

August 2004

\begin{abstract}
In this paper, we question whether there is a catch-up effect or announcement effect in Foreign Direct Investment (FDI) from the European Union (EU) to the ten EU accession countries. We study FDI outflows from the Netherlands, a small open economy with few historical ties to Eastern Europe, and compare FDI in the transition countries in Central and Eastern Europe to FDI in other regions - most notably to transition countries in Central Asia. In our analysis we try to impose as little structure as possible on the data and allow for heterogeneity within the different regions. In an effort to improve on past studies in the same area, we use a very broad sample of countries, we present country-specific results and test how robust regional dummies are, we check for omitted variable bias and we try to correct for possible non-linearity in the gravity relationships. We find that many of the differences in results of previous studies can be attributed to these specification problems. There is no evidence that an overall catch-up effect or announcement effect exists. Rather, economic fundamentals explain differences in inward investment in the region. FDI and trade are mostly complementary and there is no evidence that there is crowding out between regions.
\end{abstract}

Key words: gravity model, foreign direct investment, Eastern Europe JEL classification: F02, F21, O16, O18, P34, R58

$\overline{1}$ This paper was written when Jaap Bos was working at the Supervision Depart- 


\section{Introduction}

In the years 1989 and 1990, most of the countries in Central and Eastern Europe and Central Asia started the transition from communist states to market economies. Liberalizing markets, allowing foreign goods and services to enter the market either through trade or direct investments, was one of the major aspects of transition.

Soon after the start of this transition, it became clear that there was a large deviation in the amounts of direct investment received by the various transition countries; a few countries receive a large proportion of the total inflows whereas most other countries in the region received very low amounts of Foreign Direct Investment (FDI) inflows. Although many studies show that the size of the FDI inflows can largely be explained by a limited number of basic country characteristics (cf. Brenton et al., 1999), the question remains whether FDI flows to these transition countries can be explained in the same manner. Specifically, an announcement effect or a catch-up effect may explain the relatively high FDI flows to those transition counties that have been selected for accession in the European Union (EU).

In this paper, we study FDI flows to the ten European Union (EU) accession countries in Central and Eastern Europe (CEEC). ${ }^{2}$ We try to find out why some transition economies receive relatively more FDI than other countries. In addition, we ask if the investment flows can be explained by the degree of economic reform or development of the respective countries, or whether the EU accession countries have received a preferential treatment from EU firms that cannot be explained by economic fundamentals.

There are several important reasons for studying these investment flows. First, the more integrated the EU accession countries are with the EU, the smoother the accession to the EU is expected to be. Second and somewhat counter to the

ment of De Nederlandsche Bank. We thank Allard Bruinshoofd, Ralph de Haas, Jan Kakes, Ben Kriechel, Iman van Lelyveld, Chris de Neubourg, Gerard Pfann and seminar participants at De Nederlandsche Bank for their comments. We also thank De

Nederlandsche Bank and specifically Danny van de Kommer and Hans Ammerlaan for constructing and providing this excellent database. The usual disclaimer applies. The views expressed in this article are personal and do not necessarily reflect those of De Nederlandsche Bank.

2 Since the focus is on transition countries, there are only 10 countries included as E.U. accession countries, of which eight countries are joining the E.U. in 2004 (Czech Republic, Estonia, Hungary, Latvia, Lithuania, Poland, Slovak Republic and Slovenia) and two countries are still negotiating E.U. accession (Bulgaria and Romania). The remaining three countries joining the E.U. or negotiating (Cyprus, Malta and Turkey) are not in transition from a socialist state to a market economy and thus not considered as E.U. accession country in this chapter. 
previous argument, those accession countries that currently experience levels of investment flows below what is expected, stand to gain the most from future EU accession. Third, the stage of and relative position in the accession process influence net investment flows to the different countries entering the EU. Fourth, a medium- to long-term catch-up effect of the transition countries needs to be financed. There is ample evidence in both the more theoretically oriented growth literature (see Barro (1997) for an overview) and the more empirically oriented research into the finance-growth nexus (De Haas (2002), Szanyi (1998), EBRD Transition Report (1999), Borenszstein, de Gregorio and Lee (1998)) that significant well-allocated investments are crucial to a country's ability to structurally enhance its economic growth. At the same time, there is evidence (Koivu (2002), Bonin and Wachtel (2000) and Pissarides (2001)) that the financial system that serves to facilitate and channel investments is still underdeveloped in (most of) the transition countries. FDI can play a very important role in providing these countries with the necessary investment money. Finally, whereas research of trade flows is frequently undertaken, studies on FDI flows are still relatively rare for Central and Eastern Europe.

In this study, we try control for three common problems that have plagued these studies. First, we try to avoid selection bias. Although we focus on accession countries in Central and Eastern Europe, we also include transition countries in Central Asia in particular and a broad sample of other countries in general. Second, we try to avoid omitted variable bias. We do not limit ourselves to the standard set of variables used in comparable studies. Instead, we collect a large database with economic, geographic, religious and cultural variables that can explain differences in investment inflows and can help control for country-specific effects and study country-by-country results. Third, we try to avoid possible misspecification of our model by allowing for possible nonlinearity in the relation between our explanatory variables and FDI, respectively.

In order to see whether there indeed is a split between advanced and less advanced transition countries, we use FDI outflows from the Netherlands, a small, open EU economy with no historical ties to the CEE region. Dutch foreign direct investment outflow constitutes on average 7.22 percent of its GDP over the period 1987-2001 and 12.57 percent in 2001 and is directed towards a large number of countries. ${ }^{3}$ Central and Eastern Europe and Central Asia jointly received only 3,8 percent of the total Dutch FDI stock in 2002. However, the region currently receives a larger share of Dutch FDI than can be expected based on their 2002 FDI stock. In 2003, these countries received 8,2 percent of the Dutch outward FDI. The database we use consists of a balanced panel of FDI flows to 207 countries over the period 1987-2001, as well

3 Sources: DNB and the OECD. 
as 1987 FDI stocks. These data are matched with a large, unbalanced panel of economic and socio-political data from other sources. ${ }^{4}$ We use the resulting unbalanced panel and take a general-to-specific approach in our empirical section.

This paper contributes to the existing literature in two ways. First, the scope and depth of the data set allow us to expand beyond the standard gravity model considerably. It includes FDI determinants for a large group of 207 countries, over a relatively long period of 15 years. In addition, the analysis is not limited to basic macroeconomic fundamentals, but takes into account other factors that influence the distribution of FDI flows. The second contribution to the literature is that we present simple methods to correct some important recurring problems that can bias this type of study.

The remainder of this paper continues as follows. In section 2, we present the standard gravity model, discuss recent advances with respect to the estimations of gravity models and elaborate on a number of inherent problems with the standard gravity model. Section 3 contains an overview of studies that have applied this model to Central and Eastern Europe. In section 4, we describe our data. Section 5 contains the empirical results. Section 6 concludes.

\section{Methodology}

In this section, we describe our workhorse model for analyzing whether or not the transition countries in Central and Eastern Europe receive a proportional share of Dutch FDI when compared to transition countries in Central Asia and the rest of the world. We start with a critical discussion of the standard gravity model. Subsequently, we introduce a comprehensive way to solve some of the problems often encountered when estimating this model. In trying to present solutions to these problems we always opt for the simplest possible method, in line with the highly applied nature of the gravity model.

FDI flows are generally volatile and differ significantly between countries and over time. The gravity model is often used in order to explain some of this high variance observed in the FDI flows. The basic gravity model was developed in the 1960s to explain bilateral trade flows from a home country $i$ to host country $j$ (Linneman (1966), Bikker (1982 \& 1987), Morsink (1997), Brenton et al. (1999)). The concept of gravity refers to the forces that are expected to, over time, bring actual FDI flows in line with expected flows. The gravity model is of a highly applied nature. Much of its success can be attributed to its remarkable predictive power and its intuitive appeal. The latter can be seen from the basic gravity equation (applied to FDI and in line with Deardorff

$\overline{4}$ IMF, World Bank, Euroscope, Euromoney, CIA. 
(1995)):

$$
F D I_{i j}=A_{i j} *\left(\left(G D P_{i} * G D P_{j}\right) / D i s t_{i j}\right)
$$

where $F D I_{i j}$ is the actual FDI flow from home country $i$ to host country $j$; $G D P_{i}$ is the actual GDP of the home country; $G D P_{j}$ is the actual GDP of the host county; Dist ${ }_{i j}$ is distance between the home country $i$ and host country $j$.

This equation is a long-run equilibrium condition and in the long run we expect $F \hat{D} I_{i j}=F D I_{i j}$. In the short run, however, this equilibrium condition does not have to hold. Hence, if $F \hat{D} I_{i j}>F D I_{i j}$ a country receives less FDI than expected based on the gravity variables, and if $F \hat{D} I<F D I_{i j}$ a country receives more FDI than expected. The model is multiplicative in order to ensure that as $G D P_{i}$ (or $G D P_{j}$ ) approaches zero, so does $F D I_{i j}$. Thus, in this basic model $G D P_{i}$ and $G D P_{j}$ measure the relative potential to invest. Second order effects from $G D P_{i}$ and $G D P_{j}$ are negative. It also follows that $D i s t_{i j}$, the distance between countries $i$ and $j$, is always strictly positive. Finally, the model includes a proportionality vector $A_{i j}$. When applied to predict FDI flows, population size of both home and host country are often included as variables in $A_{i j}$, assuming larger populations support and attract larger FDI flows:

$$
F D I_{i j}=A_{i j} *\left(P O P_{i} * P O P_{j}\right) *\left(\left(G D P_{i} * G D P_{j}\right) / D i s t_{i j}\right)
$$

where $F D I_{i j}$ increases with $G D P_{i}$ and $G D P_{j}$. In the basic model, we assume that the population of the home and host country are the only two proportionality variables included. Therefore $A_{i j}$ becomes a constant $A$, and the basic model can be rewritten as:

$$
F D I_{i j}=A *\left(P O P_{i} * G D P_{i}\right) *\left(P O P_{j} * G D P_{j}\right) *\left(1 / D i s t_{i j}\right)
$$

Now FDI flows are defined as a function of per capita GDP in two countries and the distance between these countries. Since is equal for all host countries and thus cannot explain deviations over countries, the term is dropped. ${ }^{5}$ When taking logs, we now estimate:

$$
\ln F D I_{i j}=\beta_{0}+\beta_{1} \ln G D P_{j}+\beta_{2} \ln P O P_{j}-\beta_{3} \ln D i s t_{i j}+\varepsilon_{i j}
$$

A simple constant $\beta_{0}$ and the population in the host country now capture proportionality. The gravity model predicts that the coefficients $\beta_{1}$ and $\beta_{2}$ are positive, since investments are expected to be larger if the host market is larger and more developed. Distance can have a negative effect, since countries that

$\overline{5 G D P}_{i} / P O P_{i}$ is not constant over time, but there is no deviation with respect to the various host countries, thus it can not be a source of explanation for FDI deviations to those host countries. 
are farther apart are likely to have larger economic and cultural differences thus making FDI less attractive. However, distance can also have a positive effect, since an increase in distance means that trade (through an increase in transportation costs) becomes more expensive and is substituted by FDI. Distance itself is then both geographical and psychic distance. ${ }^{6}$ Therefore, the coefficient can be either positive or negative depending on which effect dominates.

Generally, studies using the gravity model can suffer from various problems: in this paper we try to deal with sample bias, omitted variable bias and nonlinearity

\subsection{Sample bias}

In terms of the model we just outlined, what is the optimal size of $j$ ? In estimating a model of this nature, we face a trade-off between broadening the sample to include more countries and risking incorrect inferences as a result of inappropriate pooling of countries that are structurally different (cf. Blonigen and Wang (2004)). As an example, consider a study where we estimate the standard gravity model for FDI flows from the Netherlands to the EU and EU accession countries. We may be tempted to conclude that a significant number of accession countries receive less FDI that can be expected. However, in a study where we also include flows to other developing and emerging countries, this conclusion may easily be reversed. In this study we broaden our sample as much as possible, provided we have enough additional variables to correct for possible remaining unobserved heterogeneity. Table 7 in the appendix contains a list of all countries included in the present study.

\subsection{Omitted variable bias}

This brings us to a related problem: how do we correct for heterogeneity? We started with the basic gravity model, with a proportionality variable $A_{i j}$ including only population of the home and host country and a constant. In order for the model to result in a good predictor for long-run FDI flows, we want to minimize $\left|F \hat{D} I_{i j}-F D I_{i j}\right|$. Put differently, we expand the vector $A_{i j}$ so as to minimize the prediction error. We do so by taking a general-to-specific approach in finding additional determinants of FDI with which we can extend the model. In table 8 in the appendix, we given overview of all the variables we considered, their expected sign and whether they were included in the extended gravity equation discussed in this paper.

$\overline{6}$ Psychic distance covers geographical, cultural, legal, religious, linguistic, historical, economic and ethnic aspects of the differences between two locations of business activity. In practice, geographical distance is a proxy for psychic distance. See Meyer (1998, pp.101) or Johansson and Wiedersheim-Paul (1975). 
Another solution would be to specify group-specific constants $A_{k}$, to be used as regional dummies (cf. Döhrn (1996)) that measure structural excesses or shortages in FDI. To the extent that the heterogeneity in investment behavior manifests itself within regions, these dummies may bias conclusions regarding structural FDI received within the region. We focus on the performance of individual transition countries and suggest three approaches. First, we test the sensitivity of our results to different specifications for $A_{k}$. Second, we analyze the extent to which individual countries structurally receive over- or underinvestment and/or if there are certain turning points in time. Finally, we graphically demonstrate the country-specific pattern of actual investments vis-à-vis predicted investments.

\subsection{Nonlinearity}

The last problem we deal with refers to nonlinearity. In the basic model we have a relationship $F D I=f\left(A_{i j}, G D P_{i}, G D P_{j}, D i s t_{i j}\right)$, which we assume to be linear in logs. But can we be certain that for each measure $k, \partial \frac{F D I_{i j}}{C_{k i j}}$ is strictly positive or negative? A certain control variable may not have the same impact on countries that receive more FDI than expected and countries that receive less than expected. This nonlinearity may hold especially for countries that receive, proportionally, very high or low amounts of FDI. As an example, think of oil-producing countries that receive a lot of investments. Given the high degree of irreversibility of oil investments and the high stakes involved, although an increase in political risk is expected lower investments, this may not hold for these countries that receive a lot of investments. As Deardorff (1995) has convincingly shown, there is no straightforward theoretical underpinning for the gravity equation. This inherent identification problem leads us to an approach that is highly data driven.

For any distribution of the residual $\varepsilon_{i j}$ from the standard gravity equation, we can conclude that countries with positive values of $\varepsilon_{i j}$ receive more investment and countries with negative values of $\varepsilon_{i j}$ receive less investment than expected based on the standard gravity equation. Thus, it is possible to identify what we define as $F D I^{+}$(over-investment) and $F D I^{-}$(under-investment). And for any distribution of $\varepsilon_{i j}$, one can be certain that the higher (lower) its value for a country $i$, the higher the probability that there is indeed $F D I^{+}\left(F D I^{-}\right)$. We therefore create separate dummy variables for the 50 percent largest positive (for $F D I^{+}$) and negative (for $F D I^{-}$) value of $\varepsilon_{i j} .{ }^{7}$ The interaction terms of

7 Specifically, we use the basic gravity model to identify the residuals. These residuals are divided in two strata, the positive residuals and the negative residuals. Since we assuming the residuals have a normal distribution with mean zero, approximately half of the residuals will be positive and half will be negative. Of the positive (negative) residuals we select the 50 percent highest (lowest) values as $F D I^{+}\left(F D I^{-}\right)$. Again, assuming the normal distribution, the group of $F D I^{+}$will consist of roughly 
these dummy variables with the FDI determinants in the gravity model, allow to identify $A^{+}, A^{-}$and $A$. For the model becomes:

$$
\begin{aligned}
\ln F D I_{i j}= & \beta_{0}+\beta_{1} \ln G D P_{j}+\beta_{2} \ln P O P_{j}-\beta_{3} \ln D i s t_{i j} \\
& +\sum_{k=1}^{K} \beta_{4, k} \ln C_{i j k}+\sum_{k=1}^{K} \beta_{5, k} D^{+} \ln C_{i j k}+\sum_{k=1}^{K} \beta_{6, k} D^{-} \ln C_{i j k}+\varepsilon_{i j}
\end{aligned}
$$

where $D^{+}$and $D^{-}$are dummy variables for countries with $F D I^{+}$and countries with $F D I^{-}$, based on the standard gravity equation. This way, we can measure the marginal effect of a determinant $k$ on over-investment respectively underinvestment and test whether this impact is significantly different from what we observe for the observations where investment is in line with what can be expected, based on standard gravity model. ${ }^{8}$

Summing up, we have introduced the gravity model used to study FDI flows and identified three potential weaknesses that we deal with in this paper. In the next section, we provide an overview of studies that have used a gravity model to study investment in the accession countries, in order to find out to what extent these studies may be biased by these weaknesses.

\section{Literature}

This section contains a brief overview of the literature that uses the gravity model as the basic vehicle to study relative investment flows. We focus on studies that have estimated this model for transition economies. Table one presents an overview of studies that have adapted a (somewhat extended) version of the standard gravity model to transition economies.

Döhrn (1996) focused specifically on EU enlargement and its role in channeling investment flows from the EU to the CEEC. He includes a variable that measures net trade flows and makes trade orthogonal on (factors that explain) FDI in order to better capture possible substitution effects between trade and

25 percent of all observations and the $F D I^{-}$observations will be about 25 percent of the total observations as well. However, if the distribution of the residuals is deviating from the normal distribution, it is with this selection method possible to have for instance 20 percent of the observations defined as $F D I^{+}$and 30 percent as $F D I^{-}$. The sum of the observations in the $F D I^{+}$and $F D I^{-}$groups always equals 50 percent of the population.

8 The decision to define over-investment and under-investment at the 50 percent level is arbitrary. In order to find out how sensitive the approach is to the choice of 50 percent as a cut-off point, the percent age over- and underinvestment has been set at different levels between 25 percent and 75 percent, in order to check whether the model fit and marginal effects change significantly. The regressions using 50 percent as boundary gave the best fit, coefficients did not change in signs or significance. 
FDI. To reduce bias from differences in starting levels of investment, Döhrn estimates the model both with FDI flows and FDI stocks as dependent variable. Although the results included in table 1 are for the flow estimations, the results for stock estimation are qualitatively similar. The models are estimated using OECD data for 1990-1992. The coefficient for GDP has the expected, positive sign, distance has a negative sign. On the basis of these estimations, Döhrn concludes that "the enlargement of the EU as well as the transformation in Eastern Europe have significant consequences for international FDI. The magnitude of the impact of the EU enlargement, however, is far from being clear. This is due to the fact that the rather complex process of 'integration' can be introduced into the regressions only by some dummy variables" (p. 130).

Table 1: Overview of Comparable FDI Gravity Studies

\begin{tabular}{|c|c|c|c|c|c|c|c|}
\hline Paper & Characteristic & GDP & POP & DIST & Period & Obs. & Adj. R-sq • \\
\hline Bevan \& Estrin (2000) & Level estimation $(\operatorname{model} 1)$ & + & - & n.a. & 1994-98 & 558 & 0.35 \\
\hline Bevan \& Estrin (2000) & First differences (model 2) & + & insig & n.a. & 1994-98 & n.a. & 0.05 \\
\hline Brenton et al. (1999) & Bilateral gravity & + & - & - & $1982-95$ & $304-514$ & $0.33-0.60$ \\
\hline Brenton \& Di-Mauro (1999) & Extended gravity model & + & - & - & $1992-95$ & $122-159$ & $0.50-0.64$ \\
\hline Buch et al. (2001) & Substitution with trade & + & $+/-$ & - & 1991-97 & $+/-30$ & $0.40-0.60$ \\
\hline Döhrn (1996) & Trade orthogonal on other factors & + & n.a. & - & $1990-92$ & 310 & $0.44-0.78$ \\
\hline Garibaldi et al. (2002) & FDI and portfolio investment & + & + & n.a. & 1990-99 & $145-179$ & $0.90-0.93$ \\
\hline
\end{tabular}

Buch et al. (2001) also look at possible substitution effects. They focus specifically on substitution between different regions, and estimate a basic model using FDI from Austria, Belgium, France, Germany, Italy, the Netherlands, the U.K., U.S. and Japan to 48 host counties for 1991, 1993, 1995 and 1997. ${ }^{9}$ Using out-of-sample tests, specifically for Germany, the authors find no evidence of substitution of FDI flows from southern countries to the CEEC. They conclude that the observed increase in FDI to the CEEC can be explained as a stock adjustment.

The results of Bevan and Estrin (2000) are somewhat difficult to compare with Buch et al. (2001), since distance is missing in their analysis and since there is no overlap with respect to the period estimated. Bevan and Estrin use bilateral FDI flows from the EU-14 (Belgium and Luxembourg are merged), Korea, Japan, Switzerland and the U.S. to the CEEC. They estimate a panel of 151 bilateral FDI connections, for the period 1994-1998. Again, the coefficient for GDP carries a significant, positive sign. Population negatively and significantly affects the FDI stock. With an adjusted $R^{2}$ (R-sq. adj.) of 0.35 , the fit is remarkably low. With the help of structural shift dummy variables

9 They also run a separate analysis for FDI flows from Germany to 37 countries, for the period 1981-1997. Results for this analysis are not presented here, but are very similar. 
for key announcements of progress in EU accession, the authors show that EU accession has influenced FDI, but country credit ratings have no effect. When the analysis is performed using first differences (model two), results remain qualitatively the same, but the fit worsens to 0.05 .

Brenton et al. (1999) use a bilateral gravity model approach to assess the impact of the deepening integration between the EU and the CEEC, in an attempt to see whether an increase in the attractiveness of the CEEC to foreign investors has affected the magnitude of FDI going to other European countries. The authors add an adjacency variable and separate the two possible effects distance has on FDI (as mentioned above). The authors test what the effect is of concurrent trade and investment liberalization. Their methodology differs somewhat from the studies discussed so far. First, they estimate a gravity model using FDI stocks, as well as a gravity model using exports and imports. Next, they use the residual from the FDI regressions in the import and export regressions in order to assess the impact of FDI on bilateral trade. They let these residuals interact with dummies for different groups of countries. Finally, they investigate "whether changes in FDI flows to particular countries or regions, in response to an increase in economic integration, had a noticeable impact upon the flows of FDI going to other, excluded, regions" (p. 119). They do so by graphically comparing the distribution of FDI flows over time (specifically for Spain and Portugal). The analysis is performed for all EU countries. Table 4.1 shows that the coefficient for GDP carries the expected positive sign. Population is negative, as is distance. Again, however, no substitution effect between FDI and trade is found. For Spain and Portugal also no evidence for substitution of FDI between the CEEC and other European countries is found.

In Brenton and Di Mauro (1999), the main aim is to check whether inflows of FDI from EU countries to CEEC are "disappointingly low" (p. 59). Both for (net) exports and FDI, Brenton and Di Mauro first estimate an extended gravity model, with dummy variables representing preferential relationships. Next, they regress the residuals from the trade model on the residuals from the FDI model, in order to find out whether there are substitution effects. The analysis is performed with pooled FDI and export data over the years 1992-1995, for Germany, France, the U.K. and the U.S. and a panel of around 35 destination countries. The fit is reasonable (R-sq. adj. ranges between 0.50 (UK) and 0.64 (France)). The results are as expected, with a positive significant impact for GDP. The distance variable is negative and significant, indicating that countries further away receive less FDI inflow. Population is insignificant. The authors conclude that "the amount of overseas investment by EU countries in the more advanced transition economies [is] already greater than one would expect given their current level of income" (p. 59). With respect to regional preference, Brenton and Di Mauro find that EU countries receive about three 
times more FDI from their EU neighbors Germany, France and the UK than can be expected based on the gravity model. The transition countries Poland, Hungary and the Czech Republic receive more FDI than the gravity variables predict as well, but Romania and Bulgaria receive a smaller share than expected based on their gravity variables. Contrary to some of the other studies described so far, they find complementarities between exports and FDI.

Garibaldi et al. (2002) go one step further and distinguish between different types of capital flows. They estimate an extended gravity model for both FDI and portfolio investment. Their study is - indirectly - motivated by the fact that, unlike FDI, portfolio investment does not involve large sunk costs. As a result, the portfolio investments can be withdrawn rather quickly in adverse conditions. This possibility to withdraw the money puts the transition economies at a risk, especially in times when they desperately need foreign capital. Garibaldi et al. (2002) try to find differences between the behavior of both types of capital. They use data for the CEEC and the former Soviet Union for the period 1990-1999. Their gravity variables carry the expected sign and indicate a diverse pattern for overall capital flows. However, FDI is found to be a "relatively stable source of financing in most countries during the early transition years and continued to play an important role in most [...] countries at least until 1998" (p. 30). In contrast to FDI, "portfolio investment is very poorly explained by fundamentals" (p. 30).

Summing up, the results of empirical research using the gravity model indicate that a higher GDP in a host country leads to higher FDI inflows. However, contradicting the expectations, a larger population does not always lead to a larger FDI inflow. Smaller countries receive relatively more investments. Distance between the host and home country limits FDI flows. In general, studies cited so far conclude that Central and Eastern European countries receive what can be expected on the basis of the simple gravity model.

\section{Data}

The database we use for this research includes yearly data for 207 countries for the period of 1987 to 2001 (see table 7 in the appendix). FDI flows are aggregated investment data from the Netherlands Central Bank (DNB). GDP and population data are taken from the World Development Indicators 2001 (WDI). Distance in kilometers $(\mathrm{km})$ is calculated based on the geographic coordinates of the country capitals. ${ }^{10}$ Quarterly flow data are accumulated to yearly flow data and converted from Dutch Guilders to USD using the average yearly exchange rate. In the literature, there are two approaches for dealing with negative and zero values of FDI flows and GDP. Either all negative or

10 The dataset contained 441 observations with missing values of GDP or distances. Those observations were dropped from the analysis. 
zero values of FDI and GDP are deleted from the analysis, or they are replaced by a very small positive number. In our database, we can distinguish between missing data and a flow of zero. Missing data are indeed missing in the original dataset and a flow of zero in the dataset means a flow between 0 and 1.000.000 euro. We drop missing observation from the dataset and replace zero FDI flows with an average value of 500.000 euro. In addition, we drop negative values from the analysis instead of including them as a small positive value. ${ }^{11}$ The total number of observations deleted from the database is 405 on a total of 3,495 observations. ${ }^{12}$

Table 2: Economic and Geographic Classification of Transition Countries

\begin{tabular}{lllll}
\hline & & Economic division & \\
& & & \\
European accession countries & Rest of CEE & Central Asia \\
\hline division & Central & Bulgaria (negotiating) & Albania & \\
& and Eastern & Czech Republic & Bosnia-Herzegovina & \\
& Europe (CEE) & Estonia & Croatia & \\
& Hungary & Macedonia & \\
& Latvia & Yugoslavia. & \\
& Lithuania & & \\
& Poland & & \\
& Romania (negotiating) & & \\
& Slovak Republic & & Kazakhstan \\
& Slovenia & Armenia & Kyrgyzstan \\
& & Azerbaijan & Tajikistan \\
& Former & & Belarus, & Turkmenistan \\
& Soviet & & Georgia & Uzbekistan \\
& & Moldova & \\
& & Russia & Ukraine & \\
& & &
\end{tabular}

With respect to regional classifications, several dummy variables are created to capture the transition effect sufficiently. The variable "Western Europe" consists of all countries and city-states geographically located in Western Europe that are not transition economies. ${ }^{13}$ The variable "transition countries"

\footnotetext{
${ }^{11}$ Negative values mean the sum of firms in a country divested in that country in a specific year. Divesting can occur through closing or scaling down of FDI values, but also through repayment of loans undertaken in the home country. Therefore, we have to weigh the sample bias that may result from dropping these observations against the measurement bias from a non-neutral logarithmic transformation. Given the large number of country-year observations already in our database, we decide in favor of the former and drop negative values.

${ }^{12}$ Replacing all negative values with a small positive value of FDI instead of deleting them, does not change the results of the gravity regression significantly except for generating a lower fit (R-sq. adj. of 0.42), but does lead to a complete group of outliers in the error analysis in section four.

${ }^{13}$ Andorra, Austria, Belgium, Channel Islands, Denmark, Faeroe Islands, Finland, France, Germany, Greece, Iceland, Ireland, Isle of Man, Italy, Liechtenstein, Luxem-
} 
takes the value one for all countries located in Central and Eastern Europe and the former Soviet Union, undergoing the transition from a planned economy to a market economy. These transition countries are subdivided in categories marked by dummy variables, in order to take their geographic position and economic development into account. Geographically, the transition countries are divided in Central and Eastern European countries and former Soviet Union countries. Economically, there is a clear division between those countries entering the EU or negotiating EU accession which are economically most developed, the rest of Central and Eastern Europe and the countries of Central Asia. Table 2 shows this classification of countries.

Table 3: Summary Statistics

\begin{tabular}{|c|c|c|c|c|c|c|}
\hline & Western Europe & EU Accession & CEE rest I ${ }^{a}$ & CEEC rest II ${ }^{b}$ & Russia & Central Asia \\
\hline No. of countries & 25 & 10 & 12 & 11 & 1 & 5 \\
\hline Population $(\mathrm{m} \ln )$ & 20,5 & 10,4 & 20,7 & 9,5 & 144,8 & 11,3 \\
\hline GDP (mln. USD $)$ & 437891,0 & 401157,3 & 34625,7 & 9596,1 & 309951,2 & 8440,2 \\
\hline GDP per capita & 23677,9 & 4267,0 & 1348,2 & 1276,2 & 2140,4 & 706,7 \\
\hline FDI (mln. USD) & 437,8 & 24,1 & 27,2 & 1,21 & 312,6 & 0,7 \\
\hline FDI per capita & 149,8 & 1,36 & 0,33 & 0,17 & 2,11 & 0,04 \\
\hline Distance $(\mathrm{km})$ & 1023 & 1268 & 2036 & 2025 & 2157 & 4848 \\
\hline
\end{tabular}

We extend the database with macroeconomic and social indicators from the WDI database and financial variables from the IMF's International Financial Statistics (IFS) database. Given the scope of the WDI and IFS databases for the period 1987-2001, we select 60 variables. These variables are classified in sub-groups and a summary is included in table 8 in the appendix. In addition, we select three different risk indicators from the Euromoney database, reflecting country risk, political risk and economic risk. ${ }^{14}$ Summary statistics for the main gravity variables for the main regions are included in table 3 .

bourg, Malta, Monaco, Netherlands, Norway, Portugal, San Marino, Spain, Sweden, Switzerland, United Kingdom.

${ }^{14}$ Euromoney provides a score twice a year, ranging from 0 to 100 with 0 being a very high risk and 100 being a very low risk. We use yearly averages for the years after 1993, when two scores were available per year. For the years before 1993, we use the available score as a yearly average. Political risk scores are only available from 1992 onwards. The economic risk variable is available starting 1986, but 1988 and 1989 are missing. These values are substituted by the average of the 1987 and 1990 score. Country risk scores are available for all years. 


\section{Results}

Dutch yearly FDI flows are volatile and there is no clear time trend. ${ }^{15}$ In order to explain the size of the flows, we start with a basic gravity model, that we extend with regional dummies to capture the long run equilibrium level. The first analysis includes the basic gravity model variables. In line with the literature, FDI flows are higher if the GDP of the host country is higher, the host country population is larger and the distance to the host country is smaller. In table four column one the results are displayed. The joint coefficients of the basic model are significant and the explanatory power is remarkably high, given the fact that only the three basic variables are used (R-sq. adj. of 0.52). GDP and Distance are significant at a one percent level, population is insignificant. ${ }^{16}$ In dealing with the three methodological problems described in section 5, we discuss the sample bias by extending the basic gravity model with regional dummy variables (section 5.1), include additional variables to deal with an omitted variable problem (section 5.2) and add interaction terms to investigate nonlinearity (section 5.3).

\subsection{Sample bias}

In the literature, a typical way to see whether countries in the transition countries indeed receive FDI flows based on their gravity values involves adding regional dummies to the gravity equation. As mentioned in section 2 , we try to avoid the sample bias present in many gravity studies by analyzing FDI flows from the Netherlands to a very large sample of countries.

As a first step in finding out whether transition countries receive the share of FDI they deserve based on our basic gravity prediction, we use the regional dummies as defined in table 3, namely Western Europe, the EU accession countries, the rest of Central and Eastern Europe and Central Asia. If the coefficient for a dummy variable is significantly positive, a country receives more than the expected FDI inflow. If it is negative, countries in that specific region receive less Dutch FDI than expected based on their GDP, population size and distance from the Netherlands. If the coefficient is insignificant, there is no substantial evidence that a region receive proportionally more or less FDI than other countries in the world.

For the regressions including regional dummies, GDP and Population have the

\footnotetext{
${ }^{15}$ We estimated the basic gravity model with a time trend and found it to be insignificant. In fact, correlation between FDI and the time trend is also low and insignificant.

${ }^{16}$ When clustering the results over countries in order to take into account that FDI flows to a certain country may not vary too much per year, we find no changes in the result.
} 
expected positive, significant sign. The Distance effect is significantly negative: countries further away from the Netherlands, ceteris paribus, receive less FDI. The inclusion of the regional dummies indicate the performance of that region compared to general FDI flows to the world. The Western Europe dummy is highly positive and significant. It indicates that Dutch FDI in the EU was significantly higher than expected based on the gravity variables of the Western European countries. In fact, the flows were six percent higher compared to Dutch investment behavior in the rest of the world. This dummy thus compensates for the negative distance effect within the EU, being a member of the EU is more important than being at a short distance.

The coefficient for the EU accession countries is insignificant, indicating that those counties receive the expected amount of FDI. At least when it comes to foreign investments, these transition countries no longer seem to experience any negative effects. However, they also do not have the positive regional effect from being a future EU member, since the coefficient is still not significantly different from zero. ${ }^{17}$

The other two transition regions, the rest of Central and Eastern Europe and Central Asia, do not have a positive regional effect, as is reflected by the negative significant coefficients for the regional dummy. This negative effect is highest for the countries in Central and Eastern Europe that are not negotiating EU accession yet. They receive only about 20 percent of the Dutch investment inflow that is expected based on their GDP, population size and distance. $^{18}$

In specifications (3) and (4) in table 4, we include a time trend, starting in 1988. This trend variable is included to measure whether there is a catch-up effect of FDI flows from their low levels in the late 1980s and early 1990s. However, the variable time is insignificant. ${ }^{19}$

$\overline{17}$ Bulgaria and Romania are included with the EU accession countries in this analysis, even though they do not enter the EU in 2004. However, including these countries in the CEECRest group does not lead to significant changes. The EUaccession coefficient becomes higher, but remains insignificant and the CEECRest coefficient becomes less negative and remains significant.

18 The regional coefficients do not display different signs or significance when included as single dummy or jointly.

${ }^{19}$ In order to double check whether this transition effect does exist, we also performed a yearly analysis. Estimating the gravity model with regional dummies for each year separately does not alter our results qualitatively. As is the case with the time trend, there is no change in the size of the regional dummies to indicate that there is a clear transition effect. The yearly regressions for EU accession countries are always insignificant. The rest of Central and Eastern Europe and Central Asia show consistent negative coefficients, with Central Asian coefficients always insignificant. The coefficient for the rest of Central and Eastern Europe is significant, but 
However, the large impact of the regional dummy variable may have macroeconomic, social or cultural explanations. We therefore return to this issue in section 5.2, where we add several additional variables in order to see whether the large regional impact is indeed explainable by additional variables (omitted variables problem). In additional, there may simply be no regional effect. For example, the positive effect the EU accession dummy may be the result of high FDI flows to the top-three transition countries Poland, Hungary and the Czech Republic, while the remaining countries in the region attract less FDI.

Table 4: Basic Model with Regional Disparities

\begin{tabular}{|c|c|c|c|c|c|}
\hline Specification (1) & ) Basic ( & (2) All (3) & Basic incl. time (4) & All incl. Time (5) & New regional division \\
\hline \multirow{2}{*}{ LnGDP } & 0.268 & 0.215 & 0.268 & 0.215 & 0.242 \\
\hline & $(33.67)($ & $(23.79)$ & $(33.70)$ & $(23.82)$ & $(29.88)$ \\
\hline \multirow{2}{*}{ LnPop } & 0.04 & 0.141 & 0.04 & 0.141 & 0.082 \\
\hline & -1.85 & $(6.18)$ & -1.83 & $(6.17)$ & $(3.77)$ \\
\hline \multirow[t]{2}{*}{ Lndist } & -0.37 & -0.18 & -0.369 & -0.179 & -0.562 \\
\hline & $(8.46)$ & $(2.43)$ & $(8.46)$ & $(2.41)$ & (11.48) \\
\hline \multirow[t]{2}{*}{ Time } & & & 0.013 & 0.011 & \\
\hline & & & -1.57 & -1.38 & \\
\hline \multirow[t]{2}{*}{ Weurope } & & 1.507 & & 1.511 & \\
\hline & & $(6.98)$ & & $(7.00)$ & \\
\hline \multirow[t]{2}{*}{ EU1 } & & & & & 0.692 \\
\hline & & & & & $(2.74)$ \\
\hline \multirow[t]{2}{*}{ EU2 } & & & & & -1.329 \\
\hline & & & & & $(6.18)$ \\
\hline \multirow[t]{2}{*}{ Euaccess } & & 0.144 & & 0.145 & \\
\hline & & -0.72 & & -0.73 & \\
\hline \multirow[t]{2}{*}{ CEECRest } & & -1.158 & & -1.151 & -1.761 \\
\hline & & $(6.64)$ & & $(6.60)$ & $(10.58)$ \\
\hline \multirow[t]{2}{*}{ CenAsia } & & -0.974 & & -0.966 & \\
\hline & & $(4.19)$ & & $(4.16)$ & \\
\hline \multirow[t]{2}{*}{ Cen Asia 1} & & & & & -1.206 \\
\hline & & & & & $(5.46)$ \\
\hline \multirow[t]{2}{*}{ Kazakh } & & & & & -0.21 \\
\hline & & & & & -0.37 \\
\hline \multirow[t]{2}{*}{ Constant } & 1.293 & 0.053 & 1.196 & -0.042 & 3.294 \\
\hline & $(3.22)$ & -0.08 & $(2.95)$ & -0.06 & $(7.17)$ \\
\hline Obs. & 2301 & 2301 & 2301 & 2301 & 2296 \\
\hline R-sq. adj. & 0.52 & 0.56 & 0.52 & 0.56 & 0.56 \\
\hline
\end{tabular}

As the basic gravity model already shows, the amounts of FDI to transition economies vary substantially within the region since the signs and sizes of regional dummy coefficients show large deviations for the EU accession countries, the rest of the CEEC and Central Asia. Parts of these regional effects are the result of heavy influence of only a subset of countries, causing an upward or downward bias in the regional average. There can be a misspecification of the dummy variables for the regions, which leads to incorrect conclusions based on those dummies. ${ }^{20}$ Studying the average residuals from the basic gravity

only in half of the years.

${ }^{20}$ When including all transition countries as separate dummy variables, the results 
model for all the years from the transition countries gives similar results. Only Poland, Hungary, the Czech Republic, Slovak Republic and Kazakhstan have positive residuals, all other countries have negative residuals. These five countries thus positively influence the regional dummy coefficient, possibly causing the EU accession dummy to be insignificant and reducing the negative significance of the Central Asia dummy. In table 4, specification (5) we therefore include a variation of the basic gravity model using new regional dummy variable definitions. We divide the EU accession countries in an EU1 group consisting of Poland, Hungary, the Czech Republic and the Slovak Republic and an EU2 group with the remaining six countries. The dummy for the rest of the CEEC remains unchanged. Kazakhstan is excluded from the Central Asia group and included as a separate dummy. The results show that for both the EU accession countries and the Central Asian countries the coefficients change significantly. The ten EU accession countries combined had an insignificant coefficient, whereas divided in two regions, the four most advanced EU accession countries (EU1) receive significantly more FDI than predicted by the gravity variables, whereas the six remaining countries (EU2) receive significantly less. In Central Asia, Kazakhstan receives an inflow of FDI as can be expected, since its coefficient is insignificant, but the other Central Asian countries (CenAsia1) now have a larger negative significant coefficient. ${ }^{21}$ This example indicates that signs and significance of dummy coefficients should be interpreted with care.

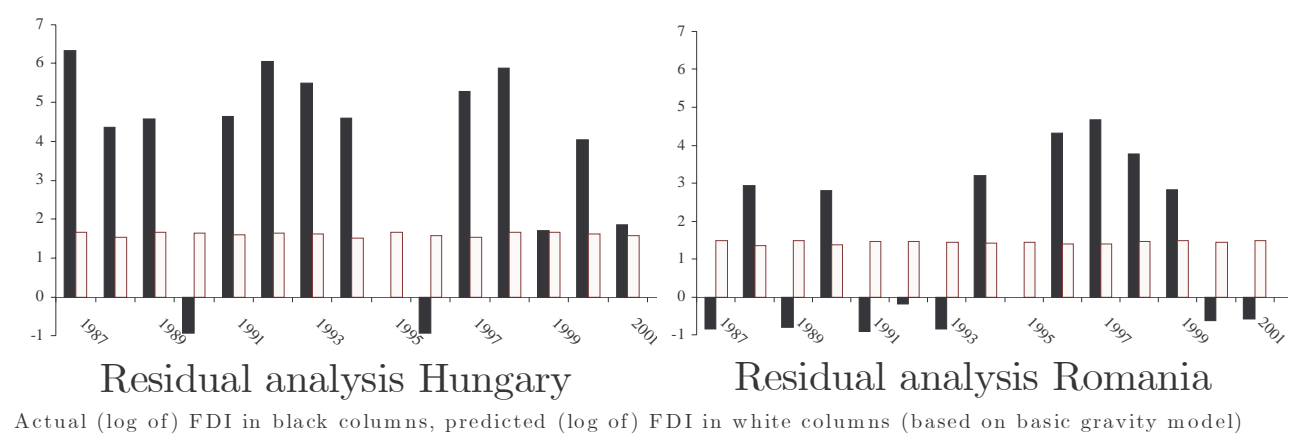

show that the Czech Republic and Hungary receive significantly more FDI than can be expected on the basis of their gravity equation and Poland is the only country with a positive insignificant coefficient. All other countries have a significantly negative coefficient, except for Azerbaijan, Bulgaria, Estonia, Kazakhstan, Romania and the Slovak Republic, that have negative but insignificant coefficients (these and other results that are mentioned but not shown are available upon request from the authors).

${ }^{21}$ We also excluded Russia from the CEECRest group and included it as a seperate dummy variable. This does not change the results, both the CEECRest dummy and Russia dummy have a negative significant sign. 
The basic gravity model only provides a long run equilibrium level and short run volatility is not taken into account. For countries reforming so drastically and only recently allowing FDI, a structural prediction model is not so valuable given that these short run developments are major determinants of FDI and largely overlooked by the basic gravity model. Still some interesting country specific findings are detected. Above, we show two examples of country specific performance and visualize the actual and predicted FDI for Hungary and Romania. As expected, the predicted FDI flows (in black) are stable, whereas actual FDI flows (in white) show more dispersion over the years.

The example of Hungary is selected since it was one of the two countries (jointly with the Czech Republic) that had a significant positive dummy coefficient when included as separate country dummy. This is an indication that actual FDI flows to Hungary consistently exceed predicted flows. Romania on the other hand shows, like most transition countries, a very volatile inflow of FDI.

Both Hungary and Romania were among the first countries to allow joint ventures including foreign participation in the early 1970s. Still, due to a very unstable political and economic climate the inflows were very limited in the 1970s and 1980s. But Hungary developed a more steady investment policy, among others allowing for 100 percent foreign investments since 1988 and the presence of these laws gave the country a head start when transition started. This legal advantage helps explain the large inflows in the early years of transition. ${ }^{22}$ Romania did not benefit from its beneficial legal structure, mainly because of the disadvantages of the Ceauscescu regime.

Some of the FDI inflows can be directly linked to the countries respective transition policies. In 1989, the year that the transition process started, the inflows of FDI in both countries were negative. Also, economic and political reforms influence FDI inflows. For example, Romania received a lot of FDI in 1995 and 1996, when they implemented their economic recovery program, but the inflow declined as quickly in the next years when the country entered a recession. The method of privatization is also important. Hungary's main form of privatization of former state owned enterprises were the direct sales, also to foreigners, encouraging FDI inflows already in the early years of transition. Romania used management-employee buy-outs as main format of privatization, a method not designed to attract FDI.

$\overline{{ }^{22} \text { Until }} 1989$, Hungary had adjusted its joint venture law frequently to adjust it to the wishes of foreign investors (see for instance Djarova, 2004). 


\subsection{Omitted variable bias}

52 percent of FDI inflows are explained by basic gravity variables, giving the long run perspective. There still is a huge volatility in FDI that is not taken into account in this model. It thus remains interesting to see which additional variables can be influential in explaining the short run volatility in FDI flows. By doing so, we deal with possible omitted variable bias. First, we add a geographic continent variable. As can be seen in table 5, the resulting coefficients are significantly different from zero. This confirms the validity of our research question: is it really geography that explains FDI flows and magnitudes, or are there different underlying reasons? To increase the understanding of the magnitude of Dutch FDI flows, specifications (2) to (8) include infrastructure and lagged FDI and variables in the categories religion, macroeconomic, sector, balance of payments and risk indicators. ${ }^{23}$ A description of all variables, the abbreviation used, how they are included and the sources, as well as the followed selection procedure of the variables is included in table 7 in the appendix.

Table 5: Gravity Model with Additional Variables

\begin{tabular}{|c|c|c|c|c|c|c|c|c|}
\hline Specification & (1) Continent (2) & Religion (3) & 3) Infra & (4) Macro (5) & Sector $(6$ & 6) $\mathrm{BoP}$ & (7) Risk (8) & F D I $[t-1]$ \\
\hline \multirow[t]{2}{*}{ GDP } & 0.162 & 0.233 & $0.238 \mathrm{GDP}$ & 0.256 & 0.242 & 0.087 & 0.095 & 0.13 \\
\hline & $(16.85)$ & $(27.56) \quad($ & $(28.46)$ & $(30.69)$ & $(28.31)$ & $(4.20)$ & $(7.72)$ & $(15.16)$ \\
\hline \multirow[t]{2}{*}{ Population } & 0.214 & 0.167 & 0.1 Population & 0.029 & 0.092 & -0.064 & 0.335 & 0.004 \\
\hline & $(8.73)$ & $(7.24)$ & $(4.45)$ & -0.4 & $(3.77)$ & -1.08 & $(10.27)$ & -0.22 \\
\hline \multirow[t]{2}{*}{ Distance } & -0.696 & -0.443 & -0.294 Distance & -0.426 & -0.407 & -0.405 & -0.165 & -0.173 \\
\hline & $(8.07)$ & $(9.88)$ & $(6.42)$ & $(9.20)$ & $(8.95)$ & $(5.09)$ & $(3.06)$ & $(4.45)$ \\
\hline \multirow[t]{2}{*}{ Africa } & -1.5089 & & Exchange rate & -0.026 & & & & \\
\hline & $(7.04)$ & & & $(5.39)$ & & & & \\
\hline \multirow[t]{2}{*}{ Asia } & -1.821 & & Labor Force & 0.045 & & & & \\
\hline & $(6.71)$ & & & -0.62 & & & & \\
\hline \multirow[t]{2}{*}{ Cen. America } & -0.709 & & Agriculture & & -0.065 & & & \\
\hline & $(2.82)$ & & & & $(5.61)$ & & & \\
\hline \multirow[t]{2}{*}{ EU accession } & -1.657 & & Industry & & 0.097 & & & \\
\hline & $(8.45)$ & & & & $(2.71)$ & & & \\
\hline \multirow[t]{2}{*}{ CEECRest } & -2.766 & & Services & & 0.145 & & & \\
\hline & $(13.47)$ & & & & $(3.45)$ & & & \\
\hline \multirow[t]{2}{*}{ Central Asia } & -2.184 & & Goods Export & & & -0.799 & & \\
\hline & $(7.34)$ & & & & & $(3.37)$ & & \\
\hline \multirow[t]{2}{*}{ Middle East } & -1.276 & & Goods Import & & & 0.88 & & \\
\hline & $(5.91)$ & & & & & $(2.57)$ & & \\
\hline \multirow[t]{2}{*}{ RestofWorld } & -0.541 & & Services Exp. & & & -0.231 & & \\
\hline & -1.9 & & & & & -1.36 & & \\
\hline \multirow[t]{2}{*}{ South America } & 0.39 & & Services Imp. & & & 0.117 & & \\
\hline & -1.4 & & & & & -0.46 & & \\
\hline \multirow[t]{2}{*}{ North America } & 1.705 & & Income Exp. & & & 0 & & \\
\hline & $(5.54)$ & & & & & 0 & & \\
\hline SE Asia & 0.265 & & Income Imp. & & & 0.793 & & \\
\hline
\end{tabular}

${ }^{23}$ Infrastructure is constructed by dividing the landarea in $\mathrm{km} 2 \mathrm{bij}$ the number of km highway in a country. 
... table 5 continued

\begin{tabular}{|c|c|c|c|c|c|c|c|c|}
\hline Specification & (1) Continent (2) & Religion (3) & Infra & (4) Macro (5) & Sector $(6$ & 5) $\mathrm{BoP}(7$ & ) Risk (8) & F D I $[t-1]$ \\
\hline & -0.94 & & & & & $(6.64)$ & & \\
\hline \multirow[t]{2}{*}{ Muslim } & & -1.248 & Trade Exp. & & & -0.054 & & \\
\hline & & $(11.98)$ & & & & -0.66 & & \\
\hline \multirow[t]{2}{*}{ Orthodox } & & -1.51 & Trade Imp. & & & -0.051 & & \\
\hline & & $(9.32)$ & & & & -0.67 & & \\
\hline \multirow[t]{2}{*}{ Buddhism } & & -1.384 & Capital Exp. & & & 0.106 & & \\
\hline & & $(7.95)$ & & & & $(2.64)$ & & \\
\hline \multirow[t]{2}{*}{ Mixture } & & -0.549 & Capital Imp. & & & -0.068 & & \\
\hline & & $(5.76)$ & & & & -1.5 & & \\
\hline \multirow[t]{2}{*}{ Other } & & -1.135 & Country risk & & & & 0.019 & \\
\hline & & $(5.55)$ & & & & & $(2.77)$ & \\
\hline \multirow[t]{6}{*}{ Infrastructure } & & & -1.157 Political risk & & & & 0.119 & \\
\hline & & & $(9.79)$ & & & & $(4.97)$ & \\
\hline & & & Economic risk & & & & 0.005 & \\
\hline & & & & & & & -1.04 & \\
\hline & & & Lagged FDI & & & & & 0.55 \\
\hline & & & & & & & & $(29.78)$ \\
\hline \multirow[t]{2}{*}{ Constant } & 5.945 & 2.69 & -2.941 Constant & 1.775 & -2.149 & -5.526 & -1.424 & 0.535 \\
\hline & $(9.65)$ & $(6.34)$ & $(5.47)$ & -1.71 & -1.72 & $(3.47)$ & $(2.80)$ & -1.52 \\
\hline Obs. & 2301 & 2301 & $2241 \mathrm{Obs}$. & 2100 & 2010 & 599 & 1303 & 1902 \\
\hline Adj. R-sq. & 0.62 & 0.56 & $0.55 \mathrm{Adj} . \mathrm{R}-\mathrm{sq}$. & 0.53 & 0.52 & 0.69 & 0.62 & 0.69 \\
\hline
\end{tabular}

All specifications have an equal or better fit than the basic gravity model and the joint variables remain significant. In addition, several of the added variables are significant. As expected, the geographical dummies included in specification (1) add a lot of explanatory power to the model. With the Western European countries as baseline category, assuming the Netherlands is trading most with other EU countries, all other continents coefficients are expected to have a negative sign. Contrary to expectations, countries located in North America attract significantly more FDI than the countries in Western Europe. With the exception of South America, South East Asia and the rest of the world, all other continents receive significantly less FDI than Western European countries.

Including religion (specification (2)) gives the expected results. Countries with a similar religion as the Netherlands (Christianity) attract significantly more FDI than countries with a predominant, different religion. There is no real difference in the size of the coefficients for the three major religions (Muslim, Orthodox and Buddhism).

Countries with a better-developed infrastructure, measured in land area divided by kilometers of highways, attract significantly more FDI than countries with a less developed roadnet (specification (3)). As countries become more developed in terms of infrastructure provisions, population size becomes less important since it becomes more convenient and less costly to do business 
also in smaller countries. ${ }^{24}$ In addition, having a large country area with a relatively small population size is not negative as long as the infrastructure is developed well.

Interpreting specification (4), including macroeconomic variables, is more difficult. The exchange rate negatively influences FDI inflows and population becomes insignificant, though the link between those two effects is unclear. Agricultural countries attract less FDI than industrial or service oriented countries (specification (5)). ${ }^{25}$ The export of goods negatively influences FDI inflows and the imports are positively significant. Thus, as exports from the Netherlands to a host country increase (imports for the host county), FDI flows also increase and thus trade and FDI are complementary. The income flows in the country also positively increase FDI. This relationship seems logical, given that FDI in essence is income to the host country. As expected, less risky countries receive significantly more FDI, with political risk being the most important risk factor. ${ }^{26}$ The (one-year) lagged FDI also positively influences this year's inflow. In this model (specification (8)), population becomes insignificant, indicating lagged FDI includes a size effect of FDI flows making country size unnecessary. ${ }^{27}$

\subsection{Nonlinearity}

Up to this point, we assume a log-linear relationship of all variables with FDI. We now investigate whether relaxing that assumption changes our analysis of FDI in the CEEC. We do so by creating interaction effects, therewith dividing our observations in three strata, that each can affect FDI differently.

In order to see if there are variables that specifically explain FDI in countries that receive proportionally a lot of (respectively very little) investments, we created two dummy variables called $\mathrm{FDI}^{+}$and $\mathrm{FDI}^{-}$(see section 2.3 ). From the countries with positive residuals in the basic gravity model, the observations within the upper half of the distribution have been marked as $\mathrm{FDI}^{+}$

\footnotetext{
${ }^{24}$ When the variable landarea in $\mathrm{km}^{2}$ and highways (measured in $\mathrm{km}$ ) are included seperately, they both have a positive significant impact on FDI.

25 This is in line with the country development path, that less developed countries often specialize more in less $\mathrm{R} \& \mathrm{D}$ intensive products such as agriculture and more developed countries specialize in industry and services. More developed countries (high GDP per capita) also receive more FDI inflows. (lnFDI $=-1.99+0.33 \ln$ GDP per capita, with GDP per capita significant at 1 percent and the R-sq. adj. $=0.44$ ). ${ }^{26}$ Also when taken separately, political risk has a significant positive coefficient of 0.19 and country and economic risk of 0.04 .

${ }^{27} \mathrm{~A}$ variable including lagged GDP has been included as well. However, the value added of this variable was minimal. Though positive and significant, the coefficient off GDP was decreasing with exactly the size of the lagged GDP coefficient. Thus GDP and lagged GDP were substitutes.
} 
observations and the observations in the lowest 50 percent of the negative residual group are marked as $\mathrm{FDI}^{-}$observations. Interaction variables are created by multiplying these dummy variables with the added variables, in order to see if some variables display different effects for countries receiving more FDI than can be expected, average receivers and countries that are receiving less FDI than can be expected. For example, a country at war will most likely receive low inflows of FDI. In addition, we expect the political stability of such a country to be lower than of countries not at war. As such, we expect the interaction variable created by multiplying the $\mathrm{FDI}^{-}$dummy and the political risk indicator to be large negative and significant, whereas we expect the coefficient to be less large for the overinvesting countries. Table seven shows the results of the eight gravity models used in table six, with the addition of $\mathrm{FDI}^{+}$ and $\mathrm{FDI}^{-}$interaction terms for all variables except the basic gravity variables. The analysis shows that for all models the fit increases significantly, with an R-sq. adj. between 0.77 and 0.94 . In all models the $\mathrm{FDI}^{-}$and $\mathrm{FDI}^{+}$interaction terms are highly significant and they carry opposite signs, whereas the coefficient and significance of the original variable diminishes. When we look at the impact of the $\mathrm{FDI}^{+}$and $\mathrm{FDI}^{-}$variables for the different specifications, we notice several interesting things. Originally, the signs for the continent coefficients South America and South East Asia were positive. Now, they have become negative. However, the coefficients for the overinvesting interaction term are high and significant at one percent level.

These countries influence the general coefficient probably to such a large extent that the coefficient became positive, whereas this positive effect now is taken into account in the interaction term. Thus, without the interaction term the conclusion of the gravity model is that these regions receive more FDI than can be expected based on their basic gravity performance. With the inclusion of the interaction term, for South America the conclusion has to be that in general this continent receives FDI according to the gravity predictions, but there are some countries within this continent that receive significantly more and some countries that receive significantly less. For South East Asia the shift is even more visible, since instead of having a positive significant coefficient, it now has a negative significant coefficient. Thus, on average countries in this region receive significantly less than expected, with an additional effect for the least receiving countries, but there also some countries that receive significantly more than predicted. This result is an indication that in those regions there are some countries that are attracting large inflows of FDI and are included in the "FDI" category. Again, this highlights the importance of the bias resulting from composing regional dummy variables. 


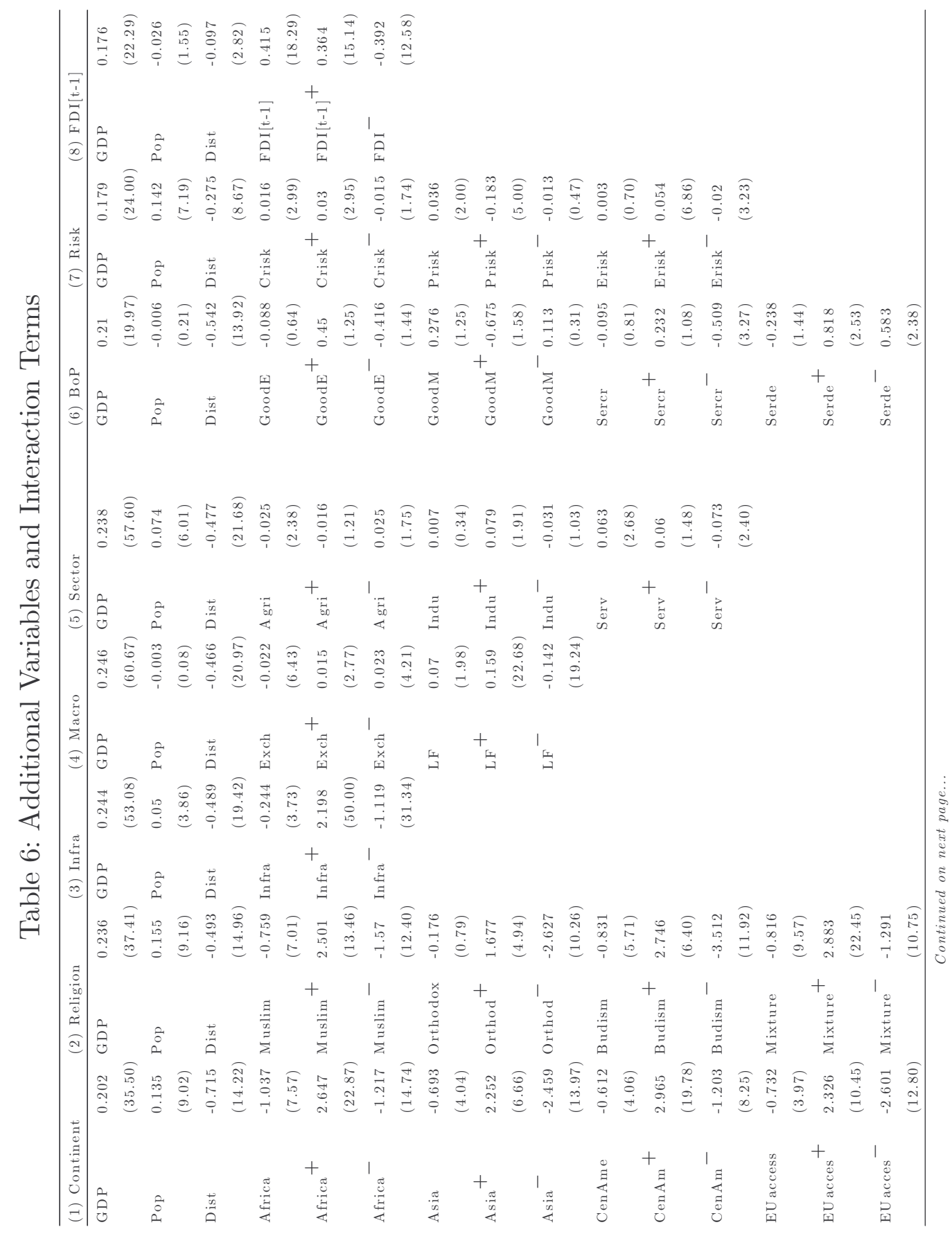

กับ 


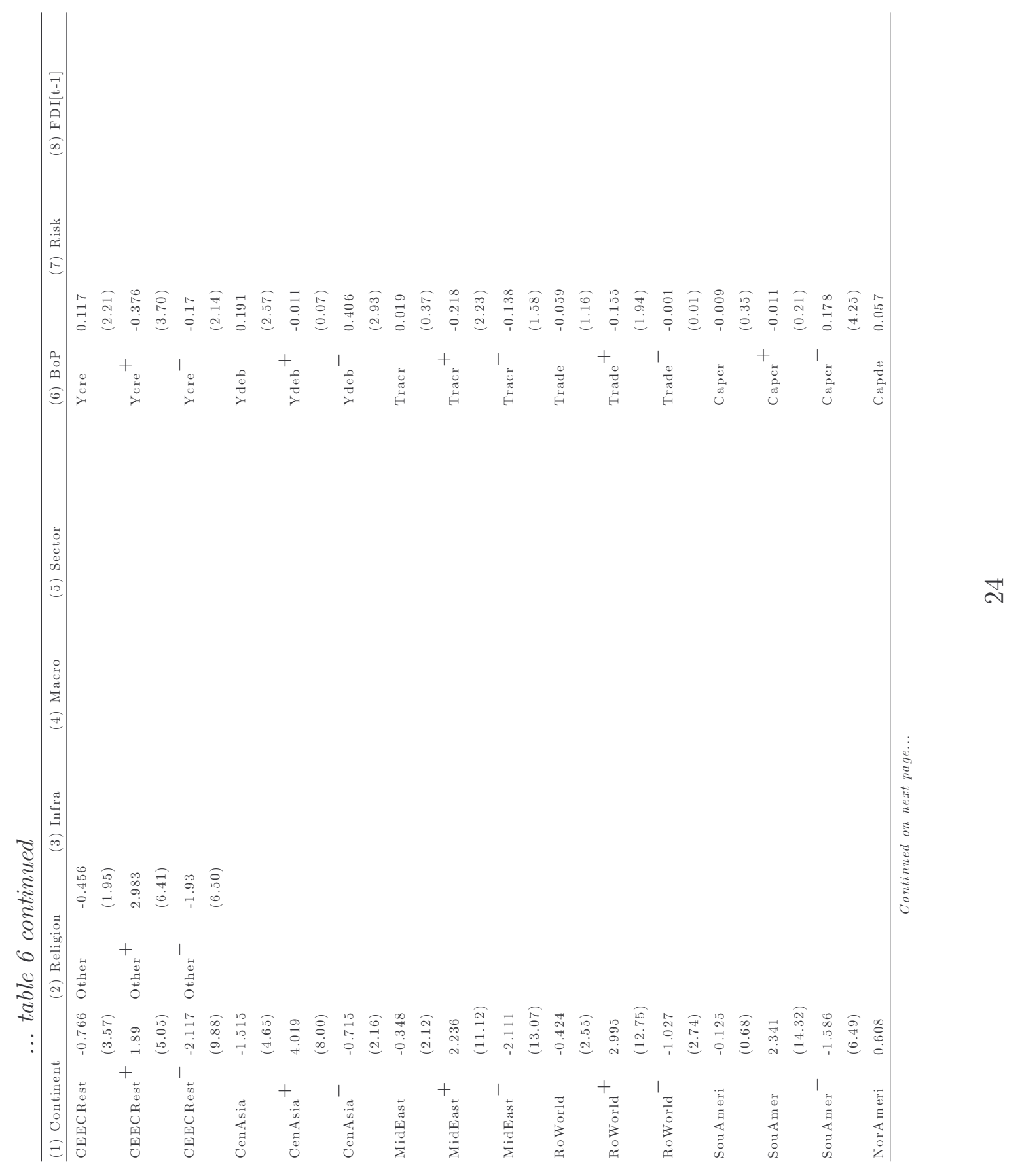



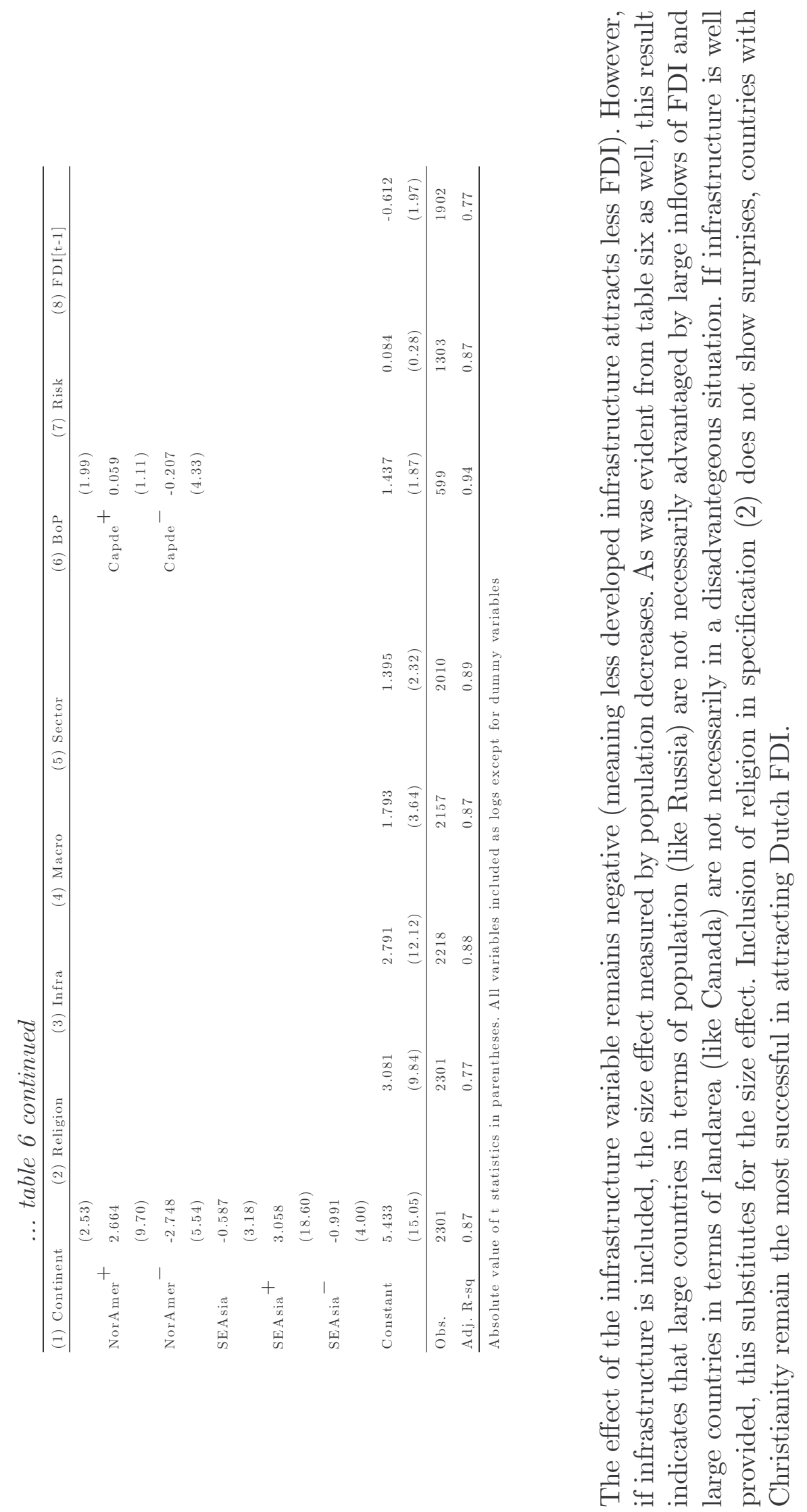
The results of specification (3) including sector-specific variables are interesting. Being an agricultural country clearly acts as a negative for attracting Dutch FDI, whereas industry has no effect and services show small positive effects. The Balance of Payment specification confirms these results. Imports and exports of goods are insignificant and the service inflows and outflows of a host country as well, except for the underreceiving host countries. Thus in general, countries imports and exports of goods and services have no clear effect on FDI inflows. This conclusion contradicts the results of table 5, where FDI and exports from the Netherlands to the host countries were complementary.

With respect to the specification including the risk indicators, it is hard to draw sensible conclusions, also because they show high correlation (0.9) and are all significant. Lower country risk (as reflected by a higher score) clearly influences FDI positively, but the political score seems to have the reverse impact. A high political risk increases Dutch FDI. The impact of lagged FDI shows the expected significant results, but does not lead to much better fit with inclusion of the interaction terms. Both adding variables to the gravity model in order to explain short-term volatility in FDI flows, as well as the definition of the regional dummy variables influence the gravity results significantly. A more elaborate analysis of the countries that receive a lot more that can be expected $\left(\mathrm{FDI}^{+}\right)$or less than expected $\left(\mathrm{FDI}^{-}\right)$can help understand FDI flows to transition countries. Because the groups of countries that receive a lot more (less) than can be expected are defined each year, trends in the inclusion of countries from the different regions in the $\mathrm{FDI}^{+}$group and $\mathrm{FDI}^{-}$group can be expected as well. For example, Western European countries receive on average relatively more FDI and are expected to be more included in the OverFDI group and less in the $\mathrm{FDI}^{-}$group than for instance Central Asian countries.

We broadly studied the division of transition countries in the OverFDI and $\mathrm{FDI}^{-}$group and found as expected that the whole region is still more included in the $\mathrm{FDI}^{-}$strata than in the $\mathrm{FDI}^{+}$strata. However, again the general geographic pattern is clear, while about 65 percent of the CEEC and Central Asian observations are included in the $\mathrm{FDI}^{-}$group, this is only 39 percent for the EU accession observations. On the other hand, only 25 percent of the EU accession observations are included in the $\mathrm{FDI}^{+}$group. This is in line with the conclusion based on the regional dummy variables; a large percentage inclusion in the $\mathrm{FDI}^{+}$group would have indicated a catch up effect even though the dummy coefficient indicates that no catch-up takes place.

\section{Conclusion}

This paper focuses on aggregate Dutch FDI flows, specifically explaining FDI inflows to Central and Eastern Europe and Central Asia. The gravity model is taken as the basic tool for the analysis. The methodology followed and data used add to the existing literature in three fields. There are substantial 
theoretical advantages, new and interesting empirical results and practical implications. Theoretically, the approach adds to the existing research in several ways. First, much can be learned from the basic gravity model when it is interpreted as a long run equilibrium model. The basic gravity variables explain FDI flows to a large extent and its explanatory power merits its inclusion in a study of this kind. However, the basic model fails to incorporate volatility of FDI flows. Thus, the unexplained variance of the basic model should be treated with care and studying this unexplained variance increases the insight into the nature and pattern of investment flows. Second, a rich and elaborate dataset can enrich the results obtained from a gravity model. Most importantly, we can avoid erroneous conclusions based on omitted countries or regions (as opposed to omitted variables). Catch-up effects of certain countries or regions can only be detected if there is a representative number of countries included to measure the general trend of FDI flows. Similarly, substitution between countries can only be proven if the pool of countries in addition to the countries studied is large enough. Finally, having a large database eliminates the chance of having a sample bias. Most gravity studies use a database including data from developed (OECD) countries as basis, since those data are most easily accessible and add data on the region studied. However, selecting countries on availability of the data most often means excluding those countries, which are relatively less developed and receive lower FDI inflows. As a result, the FDI flows will be upward biased and results derived from those data will be incorrect. By including 207 countries, the whole world, in this database and using all of the countries information to estimate the gravity model, this problem is avoided in this chapter. Third, as mentioned already, the basic gravity model is a simple linear regression, including only three explanatory variables. Besides omitting variables, also assuming linearity can be a theoretical drawback of the model. In an attempt to deal with the problem of omitted variables, 60 additional indicators have been added to the basic gravity equation. The study also allows for non-linearity, by creating dummy variables for countries receiving far more (less) FDI than can be expected based on the basic gravity modeland using those dummy variables to add interaction effects. Our results show that certain explanatory variables indeed have a relationship with FDI flows that is of a non-linear nature.

Empirically, the focus of this paper was to explain the size and pattern of Dutch FDI flows to transition countries. Our first result is that there is no evidence of an overall catch-up effect of the region. In general, the expectations are that transition countries, after having been closed for FDI for a long period, should be catching up and receiving relatively large FDI inflows. However, the more we control for the heterogeneity of the transition countries in the data set (through the inclusion of the basic gravity variables, additional variables and interaction effects), the larger the evidence that there is no such a thing as an overall upward gravity pull for these countries. There is also no 
reason to assume the flows of Dutch FDI to the EU accession countries will increase in the near future, once these eight countries join the EU. Currently, those countries have already reached their long run equilibrium level. The rest of the transition countries still receive FDI inflows below their long run equilibrium level, but those countries are not affected by EU accession. Thus, also for those countries it is not realistic to expect a more than average increase in FDI inflows in the near future. A careful conclusion that follows also from the literature overview is that past evidence in favor of such an effect is the result of measurement bias. Second, there is no reason to believe in a substitution between regions or countries purely on geographical grounds. Apparently, the nature of investments is such that the relative amount of FDI a country receives is mostly dependent on its own characteristics and far less on the region in which it is situated. The fact that Hungary and the Czech Republic receive large inflows of FDI is not due to the fact that they are situated in Central Europe. For instance the Slovak Republic, also situated in this region, is performing less in attracting FDI. Equally, the fact that the Slovak Republic is not receiving such large inflows is not caused by good results in the Czech Republic and Hungary absorbing flows that would otherwise go to Slovakia, but purely by reasons inherent to Slovakia's own country characteristics. Third, in line with what has been found elsewhere, we find some (weak) evidence of a complementary relation between FDI and trade. Thus, there is no support for the argument that firms first explore the market by exporting and engage in an FDI later. More likely, companies follow their customer. Dutch firms are exporting goods and services to Dutch companies abroad (increasing the import of the host country) and Dutch companies abroad transport or sell their goods again in the Netherlands (increasing the export of the host country).

These results have some practical implications for transition economies and businesses making investment decisions. The main lesson learnt for transition economies trying to attract FDI is that getting the basic fundamentals (price stability, growth) right is the main trigger for FDI. Given that there is no evidence of substitution of FDI between countries, a country will not attract FDI that would have otherwise gone to neighboring countries. In addition there is no specific regional effect. There is a large deviation in country performance within each region, thus the fact that a country is located in a good performing region does not necessarily mean the country is doing well in attracting FDI. Besides size, distance and economic performance, factors like historical ties, religion, accessibility and country risks influence FDI flows. For example, a stable political environment, reliable institutions and infrastructure all help increase the FDI flows. Free trade is another important factor in increasing FDI, given that trade and FDI are complementary. Opening up trade increases FDI flows and a higher FDI stock in a country again leads to higher trade. When we observe the transition countries in Central and Eastern Europe, we note that not all countries in the EU accession region are doing equally 
well in attracting FDI flows. FDI does not follow a stable time pattern, and volatility in flows over the years is high. When we look at individual countries, the Czech Republic and Hungary and to a lesser extent Poland are the star performers in the region when it comes to attracting FDI. A second tier group consists of Romania and the Slovak Republic. There is no evidence that those countries can account for large catch up effects once joining the EU in 2004. The FDI flows to other countries in the region are instable, perhaps reflecting the situation in these countries.

\section{References}

Altomonte, C. (1998), "FDI in the CEEC's and the Theory of Real Options: An Empirical Assessment", Mimeo, Katholieke Universiteit Leuven.

Altomonte, C. (2000), "Economic determinants and institutional frameworks: FDI in economies in transition", Transnational Corporations, 9 (2), 75-106.

Barro, R. J. (1997), Determinants of economic growth, MIT Press, Cambridge, Massachussets.

Bevan, A. A. and S. Estrin (2000), "The determinants of Foreign Direct Investment in Transition economies", CEPR discussion paper, 2638.

Bikker, J.A. (1987), "An International Trade Flow Model with Substitution: An Extension of the Gravity Model", Kyklos, 40 (3), 315-337.

Bikker, J.A. (1982), Vraag-Aanbodmodellen voor Stelsels van Geografisch Gespreide Markten, Toegepast op de International Handel en op Ziekenhuisopnamen in Noord-Nederland, VU Boekhandel/Uitgeverij, Amsterdam.

Blonigen, B.A. and M. Wang (2004), "Inappropriate Pooling of Wealthy and Poor Countries in Empirical FDI Studies“, NBER Working Paper, 10378, March.

Bonin, John and Paul Wachtel (2000), "Financial Sector Development in Transition economies", Ten years of Transition: the lessons and prospects, edited by M. I. Blejer and M. Skreb, Cambridge University Press.

Borenszstein, Eduardo, Jose De Gregorio and Jong-Wha Lee, "How does Foreign Direct Investment Affect Economic Growth" , Journal of International economics, vol 45, pp. 115-135, 1998.

Brenton, P.and D. Gros (1997), "Trade Reorientation and Recovery in Transition Economies", Oxford Review of Economic Policy, 13 (2), 1-11.

Brenton, P., Di-Mauro, F. and Lucke, M. (1999), "Economic Integration and FDI: An Empirical Analysis of Foreign Investment in the E.U. and in Central and Eastern Europe", Empirica, 26 (2), 95-121.

Brenton, P. and F. Di Mauro (1999), "The potential magnitude and impact of FDI flows to CEEC", Journal of economic integration, 14 (1), 59-74.

Brenton P. and F. di Mauro (1998), "Is there any potential in Trade in Sensitive Industrial Products Between the CECs and the E.U.", The world economy, $21(3)$.

Brock, G.J. (1998), "Foreign Direct Investment in Russia's regions 1993-95. Why so little and where has it gone?", Economics of Transition, 6(2), 349-360.

Buch, C.M., R.M. Kokta and D. Piazolo (2001), "Does the east get what would otherwise flow to the south? FDI Diversion in Europe", Kiel working 
paper, no 1061.

Claessens, S, D. Oks and R. Polastri (1998), "Capital flows to Central and Eastern Europe and Former Soviet Union", World Bank working paper.

Deardorff, A.V. (1995), "Determinants of Bilateral Trade: Does Gravity Work in a Neoclassical World?", in Frankel, J.A., ed. (1998), The Regionalization of the World Economy, NBER Project Report Series, Chicago and London, University of Chicago Press.

Devlin, R. et al. (2001), "Macroeconomic Stability, Trade and Integration", Integration and Trade, Jan-April, 5 (13), 35-96.

Djarova, J. (2004), Cross Border Investing; the case of Central and Eastern Europe, Kluwer Academic Publishers, Norwell, USA.

Dobosiewicz, Z. (1992), Foreign Investment in Eastern Europe, Routledge, London/NY.

Dohrn, R. (1996), "E.U. Enlargement and Transformation in Eastern Europe: Consequences for Foreign Direct Investment in Europe", Konjunkturpolitik, $42(2-3), 113-132$.

Donges, J.B. and Wieners, J. (1994), "Foreign Investment in the Transformation Process of Eastern Europe", International Trade Journal, 8 (2), 163-191.

EBRD, Transition Report 1999, Ten years of Transition: Economic transition in Central and Eastern Europe, the Baltic States and the CIS, London.

Frankel, J.A., ed. (1998), The regionalization of the world economy, NBER Project Report Series, Chicago and London, University of Chicago Press [ISBN: 0-226-25995-1].

Garibaldi, P., N. Mora, R. Sahay and J. Zettelmeyer (2002), "What moves capital to transition economies?", IMF working paper, WP/02/64

Haas, R. de (2002), "Law, Financeand Growth during Transition: A Survey", Mimeo.

Hogenbirk, A.E. (2002), "Determinants of Inward Foreign Direct Investment: The case of the Netherlands", Proefschrift Universiteit Maastricht.

Holland, D. and N. Pain (1998), "The diffusion of innovations in Central and Eastern Europe: a study of the determinants and impact of Foreign Direct Investment", NIESR discussion paper, 137.

Jensen, C. (2002), "Foreign Direct Investment, Industrial Restructuring and the Upgrading of Polish Exports", Applied Economics, January, 34 (2), 207 217.

Kalirajan, K. (1999), "Stochastic Varying Coefficients Gravity Model: An Application in Trade Analysis", Journal of Applied Statistics, February, 26 (2), 185-193.

Klein, M.W., Peek, J. and Rosengren, E.S. (2002), "Troubled Banks, Impaired Foreign Direct Investment: The Role of Relative Access to Credit", American Economic Review, June, 92 (3), 664-682.

Koivu, T. (2002), "Do efficient banking sectors accelerate economic growth in transition countries?", Bank of Finland Discussion Papers, no. 14.

Kose, A. (1999), "Review of: The Regionalization of the world economy", Journal of Economic Literature, September, 37 (3), 1190-1192. 
Koivu, T. (2002), "Do efficient banking sectors accelerate economic growth in transition countries?", BOFIT discussion paper, 14.

Lansbury, M., N. Pain and K. Smidkova (1996), "Foreign Direct Investment in Central Europe since 1990: An Econometric Study", National Institute Economic Review, May, 104-114.

Lehmann, A. (2002), "Foreign Direct Investment in Emerging Markets: Income, Repatriation and Financial Vulnerabilities", IMF working paper, WP/02/47. Linnemann, H, "An econometric study of international trade flows", Amsterdam, North Holland, 1966.

Lipschitz, L., T. Lane and A. Mourmouras (2002), "Capital flows to transition economies: master or servant?", IMF working paper, WP/02/11.

Meyer, K.E. (1995), "Direct Foreign Investment in Eastern Europe: The Role of Labor Costs", Comparative Economic Studies, Winter, 37 (4), 69-88.

Meyer, K.E (1995), "Foreign Direct Investment in the early years of economic transition: a survey", Economics of Transition, 3 (3), 301-320.

Meyer, K.E (1998), Direct Investment in Economies in Transition, Edward Elgar Publishing, Cheltenham, UK, 1st edition.

Morsink, R.L.A. (1997), "Corporate networking and Foreign Direct Investment: explaining the mosaic of geographical investment patterns under different corporate strategies", Proefschrift Erasmus Universiteit Rotterdam.

Nilsson, L. (2000), "Trade Integration and the E.U. Economic Membership Criteria", European Journal of Political Economy, November, 16 (4), 807-827.

Pissarides, F., Financial structures to promote private sector development in south eastern europe, EBRD working paper no. 64, 2001.

Portes, R., Rey, H. and Oh, Y. (2001), "Information and Capital Flows: the Determinants of Transactions in Financial Assets", European Economic Review, May, 45(4-6), 783-796.

Resmini, L. (2000), "The determinants of Foreign Direct Investments into the CEEC: New evidence from sectoral patterns", LICOS Working paper, Center for transition economics, Leuven.

Schnitzer, M. (2002), "Debt v. Foreign Direct Investment: The Impact of Sovereign Risk on the Structure of International Capital Flows", Economica, February, 69 (273), 41-67.

Stone, S.F. and Jeon, B.N. (2000), "Foreign Direct Investment and trade in the Asian-Pacific Region: Complementarity, Distance and Regional Economic Integration", Journal of Economic Integration, September, 15 (3), 460-485.

Szanyi, M. (1998), "Experiences with Foreign Direct Investment in Eastern Europe: Advantages and Disadvantages", Eastern European Economics, MayJune, 36 (3), 28-48. 


\section{Appendix}

Table 7: Countries Included in the Analysis

\begin{tabular}{|c|c|c|c|c|c|c|c|}
\hline 1 & Afghanistan & 53 & Djibouti & 105 & Latvia & 157 & Russian Federation \\
\hline 2 & Albania & 54 & Dominica & 106 & Lebanon & 158 & Rwanda \\
\hline 3 & Algeria & 55 & Dominican Republic & 107 & Lesotho & 159 & Samoa \\
\hline 4 & American Samoa & 56 & Ecuador & 108 & Liberia & 160 & San Marino \\
\hline 5 & Andorra & 57 & Egypt, Arab Rep. & 109 & Libya & 161 & Sao Tome and Principe \\
\hline 6 & Angola & 58 & El Salvador & 110 & Liechtenstein & 162 & Saudi Arabia \\
\hline 7 & Antigua and Barbuda & 59 & Equatorial Guinea & 111 & Lithuania & 163 & Senegal \\
\hline 8 & Argentina & 60 & Eritrea & 112 & Luxembourg & 164 & Seychelles \\
\hline 9 & Armenia & 61 & Estonia & 113 & Macao, China & 165 & Sierra Leone \\
\hline 10 & Aruba & 62 & Ethiopia & 114 & Macedonia, FYR & 166 & Singapore \\
\hline 11 & Australia & 63 & Faeroe Islands & 115 & Madagascar & 167 & Slovak Republic \\
\hline 12 & Austria & 64 & Fiji & 116 & Malawi & 168 & Slovenia \\
\hline 13 & Azerbaijan & 65 & Finland & 117 & Malaysia & 169 & Solomon Islands \\
\hline 14 & Bahamas, The & 66 & France & 118 & Maldives & 170 & Somalia \\
\hline 15 & Bahrain & 67 & French Polynesia & 119 & Mali & 171 & South Africa \\
\hline 16 & Bangladesh & 68 & Gabon & 120 & Malta & 172 & Spain \\
\hline 17 & Barbados & 69 & Gambia, The & 121 & Marshall Islands & 173 & Sri Lanka \\
\hline 18 & Belarus & 70 & Georgia & 122 & Mauritania & 174 & St. Kitts and Nevis \\
\hline 19 & Belgium & 71 & Germany & 123 & Mauritius & 175 & St. Lucia \\
\hline 20 & Belize & 72 & Ghana & 124 & Mayotte & 176 & St. Vincent/Grenadines \\
\hline 21 & Benin & 73 & Greece & 125 & Mexico & 177 & Sudan \\
\hline 22 & Bermuda & 74 & Greenland & 126 & Micronesia, Fed. Sts. & 178 & Suriname \\
\hline 23 & Bhutan & 75 & Grenada & 127 & Moldova & 179 & Swaziland \\
\hline 24 & Bolivia & 76 & Guam & 128 & Monaco & 180 & Sweden \\
\hline 25 & Bosnia-Herzegovina & 77 & Guatemala & 129 & Mongolia & 181 & Switzerland \\
\hline 26 & Botswana & 78 & Guinea & 130 & Morocco & 182 & Syrian Arab Republic \\
\hline 27 & Brazil & 79 & Guinea-Bissau & 131 & Mozambique & 183 & Tajikistan \\
\hline 28 & Brunei & 80 & Guyana & 132 & Myanmar & 184 & Tanzania \\
\hline 29 & Bulgaria & 81 & Haiti & 133 & Namibia & 185 & Thailand \\
\hline 30 & Burkina Faso & 82 & Honduras & 134 & Nepal & 186 & Togo \\
\hline 31 & Burundi & 83 & Hong Kong, China & 135 & Netherlands & 187 & Tonga \\
\hline 32 & Cambodia & 84 & Hungary & 136 & Netherlands Antilles & 188 & Trinidad and Tobago \\
\hline 33 & Cameroon & 85 & Iceland & 137 & New Caledonia & 189 & Tunisia \\
\hline 34 & Canada & 86 & India & 138 & New Zealand & 190 & Turkey \\
\hline 35 & Cape Verde & 87 & Indonesia & 139 & Nicaragua & 191 & Turkmenistan \\
\hline 36 & Cayman Islands & 88 & Iran, Islamic Rep. & 140 & Niger & 192 & Uganda \\
\hline 37 & Central African Rep. & 89 & Iraq & 141 & Nigeria & 193 & Ukraine \\
\hline 38 & Chad & 90 & Ireland & 142 & Northern Mariana Islands & 194 & United Arab Emirates \\
\hline 39 & Channel Islands & 91 & Isle of Man & 143 & Norway & 195 & United Kingdom \\
\hline 40 & Chile & 92 & Israel & 144 & Oman & 196 & United States \\
\hline 41 & China & 93 & Italy & 145 & Pakistan & 197 & Uruguay \\
\hline 42 & Colombia & 94 & Jamaica & 146 & Palau & 198 & Uzbekistan \\
\hline 43 & Comoros & 95 & Japan & 147 & Panama & 199 & Vanuatu \\
\hline 44 & Congo, Dem. Rep. & 96 & Jordan & 148 & Papua New Guinea & 200 & Venezuela, RB \\
\hline 45 & Congo, Rep. & 97 & Kazakhstan & 149 & Paraguay & 201 & Vietnam \\
\hline 46 & Costa Rica & 98 & Kenya & 150 & Peru & 202 & Virgin Islands (U.S.) \\
\hline 47 & Cote d'Ivoire & 99 & Kiribati & 151 & Philippines & 203 & West Bank and Gaza \\
\hline 48 & Croatia & 100 & Korea, Dem. Rep. & 152 & Poland & 204 & Yemen, Rep. \\
\hline 49 & Cuba & 101 & Korea, Rep. & 153 & Portugal & 205 & Yugoslavia, Fed. Rep. \\
\hline 50 & Cyprus & 102 & Kuwait & 154 & Puerto Rico & 206 & Zambia \\
\hline 51 & Czech Republic & 103 & Kyrgyz Republic & 155 & Qatar & 207 & Zimbabwe \\
\hline 52 & Denmark & 104 & Lao PDR & 156 & Romania & & \\
\hline
\end{tabular}




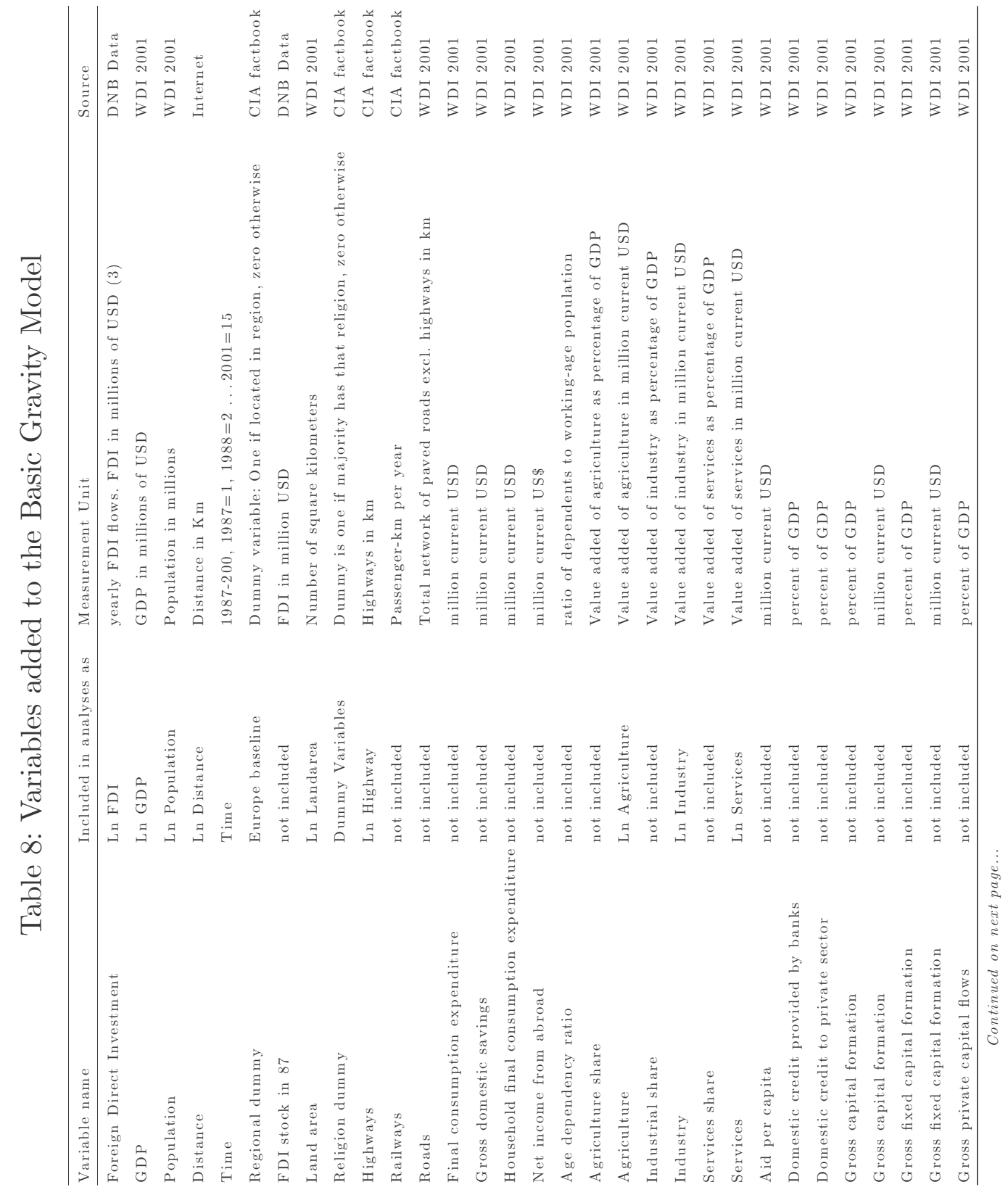

ले 


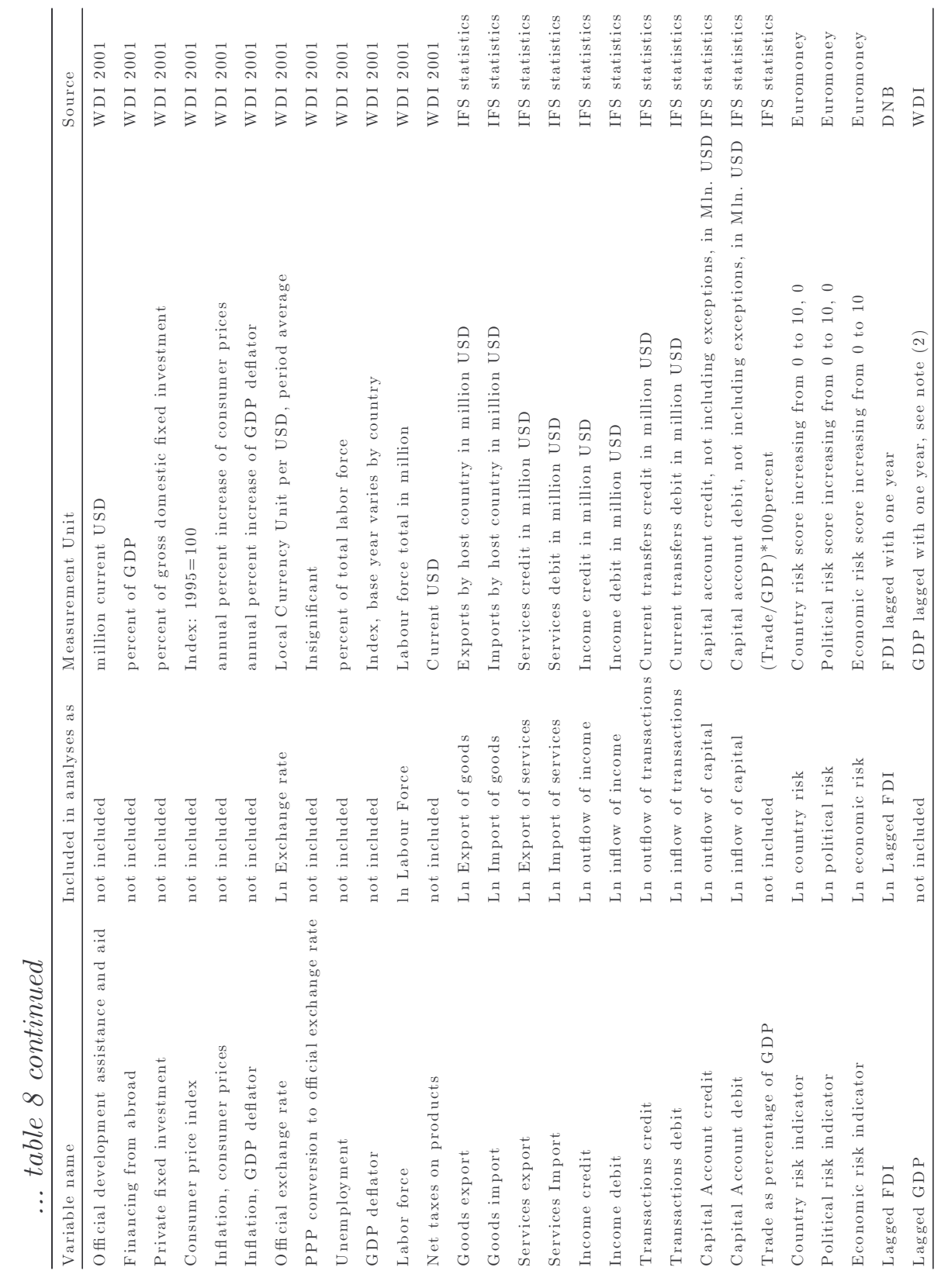

